\title{
Chemical scarification using kno3 to increase seed germination and early growth of Indigofera zollingeriana
}

\author{
E Simbolon, T H Wahyuni, N D Hanafi, Hamdan, Y L Henuk, N Ginting \\ Animal Production Program Study, Faculty of Agriculture, University of \\ North Sumatera, Medan 20155, Indonesia \\ E-mail : Erwandisimbolon@gmail.com
}

\begin{abstract}
Indigofera zollingeriana as animal feed contain high protein and a good alternative source of feed for livestok. In North Sumatera Province, now adays Indigofera has been introduced to livestockers. This study aims to determine the effect of scarification by soaking $\mathrm{KNO}_{3}$ (potassium nitrate) on seed germination and early growth of Indigofera zollingeriana. This research was carried out at Animal Production Laboratory; Animal Husbandry Study Program, Faculty of Agriculture, University of North Sumatra Jl. A. Sofyan No. 3 Medan, which began from November 2018 to January 2019. The design used was a factorial completely randomized design (RAL) with 12 combination factors, each of which contained 3 replications where each replication contained 15 seeds of Indigofera zollingeriana. The treatment consisted of 2 factors, namely the $\mathrm{K}$ factor $=\mathrm{KNO}_{3}$ concentration, $\mathrm{K} 0=$ control, $\mathrm{K} 1=4 \mathrm{~g} / \mathrm{l}, \mathrm{K} 2=$ $8 \mathrm{~g} / \mathrm{l}, \mathrm{K} 3=12 \mathrm{~g} / 1$ repeatedly, and $\mathrm{L}$ factor $=$ soaking time, $\mathrm{L} 1=4$ hours, $\mathrm{L} 2=8$ hours, L3 $=12$ hours .

The results showed that the administration of $\mathrm{KNO}_{3}$ and soaking time on Indigofera zollingeriana seeds had a significant effect on the percentage of sprouts, sprout height, and growing power. The conclusion of the use of $\mathrm{KNO}_{3}$ with levels of 4 grams and 8 grams has a positive impact on the percentage of germination and height of indigofera zollingeriana and the duration of 12 hours immersion in the seeds of indigofera zollingeriana also gives a positive effect on the percentage of sprouts and sprout height, and the best percentage of growth is on the use of 8 grams of $\mathrm{KNO}_{3}$ with 8 hours of soaking time.
\end{abstract}

\section{Introduction}

Indigofera plants (Indigofera zollingeriana) are ruminant feed which are reported to have good adaptability to various environmental conditions, such as acidic soils and high salinity soils and are tolerant of long dry climates. This plant is known to contain protein that is quite high when compared to the type of herbaceous, and therefore has the potential as a source of high protein and can be produced locally.

Germination is the occurrence of the growth of embryos in seeds into new plants. After the sprouts are produced, then the sprouts develop into small plants that already have roots, stems and leaves. Percentage of sprouts, which is the percentage of normal sprouts that can be produced by seeds in favorable conditions within a predetermined time. 
Skarification is a preliminary treatment of seeds which in the process of damage to the seed coat to be more easily penetrated by buds. Scarification is usually done on hard seed shells, for example in the seeds of lamtoro, Indigofera zollingeriana, and others usually carried out by mechanical treatment, hot water or chemical treatment using potassium nitrate.

The distribution of indigofera zollingeriana plants in North Sumatra is still too small because the percentage of sprouts that grow only ranges from $20 \%$ - $60 \%$ because Indigofera zollingeriana plants have quite small seeds and when the sprouts that grow are also small so they are very vulnerable to excessive water. Indigofera zollingeriana seeds also have a fairly hard outer skin that can affect the percentage of sprouts that grow.

Based on the description above, the researchers were interested in conducting a study of the effect of scarification with KNO3 on seed germination and early Indigofera zollingeriana growth as animal feed ingredients because the effect of immersion can affect the breakdown of dormancy in seeds so that it can affect seed germination.

\section{Materials and Methods}

The research was conducted in the field of Animal Husbandry Study Program, Faculty of Agriculture, University of North Sumatra. This research lasted for 2 months which will be held from November 2018 to January 2019.

The tools used in this study are electric scales, gauze, spoons, lopybags, glass breakers, ruler, tweezers, trays and filter paper.The ingredients used were seeds of Indigofera zollingeriana weighing $5.2 \mathrm{mg}-7.2 \mathrm{mg}, \mathrm{KNO}_{3}$ (potassium nitrate) and ultisol soil.

The concentration factor of KNO3 $(\mathrm{K})$ consists of three levels, namely:

K0: control

$\mathrm{K} 1: 4 \mathrm{~g} /$ liter of water

$\mathrm{K} 2: 8 \mathrm{~g} /$ liter of water

K3: $12 \mathrm{~g} /$ liter of water

The Soaking Duration Factor (L) consists of three levels, namely:

L1: 4 hours

L2: 8 hours

L3: 12 hours

Implementation of Research

Preparation phase

The first step that must be done before conducting this research is the preparatory stage. The collection of brown beans from Indigofera zollingeriana. Taken from the tree and left for 7 days before the treatment, collecting seeds for 7 days before planting is chosen because on the seventh day the seeds are ripe completely dry and it's maximal for multiplication. Indigofera zollingeriana seeds used come from the same tree (homogeneous) and with a seed weight of $5.2 \mathrm{mg}-7.2 \mathrm{mg}$. Implementation Phase

a. Sorting the seeds of Indigofera zollingeriana

Pernyotiran seeds is done by doing soaking the seeds in the water so that they can be seen good quality and less good seeds. Drowning seeds are seeds that are of good quality.

b. Soaking the seeds of Indigofera zollingeriana into KNO3 (potassium nitrate)

The seeds which have been through the subsequent screening process are immersed into KNO3 (potassium nitrate) as many as 15 seeds of Indigofera zollingeriana soaked in the factors and duration of immersion that has been determined before.

c. Planting seeds into containers

After the immersion process is completed in accordance with the predetermined time Indigofera zollingeriana seeds are then removed using tweezers and washed with clean water and after that placed in a container that has been given tissue and dripped with $25 \mathrm{ml}$ of water first, then put each of 15 seeds Indigofera zollingeriana. There are 3 replications for each treatment. Containers 
containing Indigofera zollingeriana seeds are then stored for 20 days and if the cotton in the container starts to dry it can be retracted with water, giving water to the cotton aims to help the seeds to germinate.

Stage of measuring the percentage of sprouts and sprout height after 20 days of germination.

a. Planting sprouts into ultisol soil

After the sprouts are measured in height and the percentage of sprouts then the sprouts are transferred into polybags that already contain ultisol soil. After the sprouts are removed, regular watering is done so that the sprouts can live in ultisol soil. After the age of 1 month, the next step is to grow the power of the indigofera zollingeriana sprouts.

Parameters measured

a. Sprout height

sprout height is measured after the seed is 30 days later. Seeds are called germinating when the leaves or roots begin to appear. The formula for looking for sprout height includes:

b. Percentage of sprouts

The percentage of sprouts is calculated after the seed is 30 days later. Seeds are called germinating when the leaves or roots begin to appear. The formula searches for the percentage of sprouts, among others:

c. Power grows

The general condition is seen in the number of leaves that grow after being planted. Growth is seen after two leaves appear. Then observed the length of the plant grows \pm 1 month.

2.4 Data Analysis

The data obtained were analyzed statistically by using a completely randomized design (CRD) with 12 combinations of treatments with 3 replications and if it had a significant effect there would be a duncan test to see differences in the observed variables.

\section{Results and Discussion}

3.1 Percentage of Sprouts

Table 1. Percentage of sprouts grown on indigofera zollingeriana. plants

\begin{tabular}{lcccr}
\hline & \multicolumn{3}{c}{ Soaking time (hours) } & \multirow{2}{*}{ Average } \\
\cline { 2 - 4 } KNO3 $(\mathrm{g})$ & $\begin{array}{c}\mathrm{L} 1 \\
(4 \text { hours })\end{array}$ & $\begin{array}{c}\mathrm{L} 2 \\
(8 \text { hours })\end{array}$ & $\begin{array}{c}\text { L3 } \\
(12 \text { hours })\end{array}$ & \\
\hline K0 (control) & 7,33 & 7,33 & 8,33 & $7,663^{\mathrm{a}}$ \\
K1 (4 g) & 8 & 7,67 & 10,33 & $8,666^{\mathrm{ab}}$ \\
K2 (8 g & 8,33 & 9 & 11,33 & $9,553^{\mathrm{b}}$ \\
K3 (12 g) & 7 & 8 & 8,67 & $7,89^{\mathrm{a}}$ \\
\hline Average & $7,665^{\mathrm{a}}$ & $8,000^{\mathrm{a}}$ & $9,665^{\mathrm{b}}$ & \\
\hline
\end{tabular}

Description: Different superscriptions in the same row or column show the real number in the

Duncan test $(\mathrm{p}<0.05)$

The results showed that the immersion time had a significant effect on the percentage of indigofera zollingeriana. Sprouts. The average value of the significant percentage of sprouts was on the treatment of 12 hours immersion time (L3) of $64.38 \%$ because the immersion treatment in water serves to wash substances that inhibit germination and can soften the seed coat. This is in accordance with the statement of Rismunandar, 1999 [1] which states that water in the germination process functions to liquefy food substances in the pieces of seeds that are distributed in the institution. 
Based on Table 2, it can be seen that the average percentage of sprouts that are significant is the treatment of KNO $8 \mathrm{~g}(\mathrm{~K} 2)$ which is $63.68 \%$ and $4 \mathrm{~g}(\mathrm{~K} 1)$ which is $57.77 \%$ because Potassium nitrate $\left(\mathrm{KNO}_{3}\right)$ contains two important nutrients needed by plants namely potassium and nitrogen. Nitrogen and potassium are the two macro elements needed by plants. This is consistent with the statement of Salisbury and Ross ,1995a [2]

\subsection{Sprout height}

Table 2. Average plant height $(\mathrm{cm})$ of indigofera zollingeriana that has been treated at $15 \mathrm{HST}$ observations.

\begin{tabular}{lllll}
\hline & \multicolumn{3}{c}{ Soaking time (hours) } & \multirow{2}{*}{ Average } \\
\cline { 2 - 4 } KNO3 (gram) & $\begin{array}{c}\text { L1 } \\
\text { (4 hours) }\end{array}$ & $\begin{array}{c}\text { L2 } \\
(8 \text { hours })\end{array}$ & $\begin{array}{c}\text { L3 } \\
(12 \text { hours })\end{array}$ & \\
\hline K0 (control) & 2,96 & 3,29 & 3,54 & $3,263^{\mathrm{a}}$ \\
K1 (4 g) & 3,34 & 3,49 & 3,66 & $3,496^{\mathrm{b}}$ \\
K2 $(8 \mathrm{~g})$ & 3,29 & 3,67 & 3,82 & $3,593^{\mathrm{b}}$ \\
K3 $(12 \mathrm{~g})$ & 3,43 & 3,53 & 4,01 & $3,656^{\mathrm{b}}$ \\
\hline Average & $3,255^{\mathrm{a}}$ & $3,495^{\mathrm{b}}$ & $3,757^{\mathrm{c}}$ & \\
\hline
\end{tabular}

Description: Different superscriptions in the same row or column show the real number in the

Duncan test $(\mathrm{p}<0.05)$

The results showed that the treatment of soaking time significantly affected the height of indigofera zollingeriana. The significant value of sprout height was in the treatment of 12 hours immersion (L3) of $3.757 \mathrm{~cm}$ and 8 hours (L2) of 3.495 because the immersion treatment in water serves to wash substances that inhibit germination and can soften the seed coat. This is in accordance with the statement of Rismunandar, 1999 [1] which states that water in the germination process functions to liquefy food substances in the pieces of seeds that are distributed in the institution.

The average value of the percentage of sprouts that was significantly different was found in the treatment of 4 hours soaking time (L1) of $3.255 \mathrm{~cm}$ because the length of immersion in water serves to wash substances that inhibit germination and can soften the seed coat. This is consistent with the statement of Sihotang, 1999 [3] which states that long immersion affects the germination rate.

Based on Table 3, it can be seen that the average sprout height is significant at the treatment of $\mathrm{KNO} 4 \mathrm{~g}(\mathrm{~K} 1)$ which is $3.496 \mathrm{~cm}, 8 \mathrm{~g}(\mathrm{~K} 2)$ which is $3.593 \mathrm{~cm}$, and $12 \mathrm{~g}(\mathrm{~K} 3)$ which is $3.656 \mathrm{~cm}$ because Potassium nitrate $\left(\mathrm{KNO}_{3}\right)$ contains two important nutrients needed by plants are $44 \%$ potassium and $12 \%$ nitrogen. Nitrogen and potassium are the two macro elements needed by plants. This is consistent with the statement of Salisbury and Ross, 1985 [2] which states that plants that are deficient in potassium will accumulate lower carbohydrates because photosynthesis runs slowly. Potassium deficiency also causes leaves to turn yellow, stems become weak and susceptible to pests and diseases and potassium is also an activator of a large number of enzymes that are important for respiration and photosynthesis.

The average value of sprout height was significantly different in the control treatment (K0) with an average value of $3.263 \mathrm{~cm}$ because there was no treatment of KNO3 so that there was no effect on the growth rate of the indigofera zollingeriana seeds. This is in accordance with the statement of Santosa et al. 2006 [4] which states that seed germination compounds function to increase the ability of seeds to germinate, as well as atonic and $\mathrm{KNO}_{3}$. 


\subsection{Power of Growth Indigofera zollingeriana}

Table 3. Average growth power of Indigofera zollingeriana

\begin{tabular}{lllll}
\hline & \multicolumn{3}{c}{ Soaking time (hours) } & \\
\cline { 2 - 4 } \multicolumn{1}{c}{ KNO3 $(\mathrm{g})$} & $\begin{array}{c}\mathrm{L} 1 \\
(4 \text { hours })\end{array}$ & $\begin{array}{c}\mathrm{L} 2 \\
(8 \text { hours })\end{array}$ & $\begin{array}{c}\text { L3 } \\
(12 \text { hours })\end{array}$ & \\
\hline K0 (control) & $24,45^{\mathrm{Aa}}$ & $22,22^{\mathrm{Aa}}$ & $28,89^{\mathrm{Aa}}$ & 25,19 \\
K1 (4 g) & $26,67^{\mathrm{Aa}}$ & $20,00^{\mathrm{Aa}}$ & $42,22^{\mathrm{Bb}}$ & 29,63 \\
K2 $(8 \mathrm{~g})$ & $33,33^{\mathrm{Ab}}$ & $44,45^{\mathrm{Bb}}$ & $37,78^{\mathrm{Ab}}$ & 38,52 \\
K3 $(12 \mathrm{~g})$ & $22,22^{\mathrm{Aa}}$ & $31,11^{\mathrm{Bb}}$ & $28,89^{\mathrm{Aa}}$ & 27,33 \\
\hline Average & 26,67 & 29,45 & 34,45 & \\
\hline
\end{tabular}

Description: Different superscriptions on the same row and column show very significant differences $(\mathrm{p}<0.01)$.

Notation using uppercase letters is the effect of immersion time while notation using lowercase letters is the effect of $\mathrm{KNO} 3$ levels.

Diversity analysis shows an interaction between the number of KNO3 And soaking time has a very significant effect $(\mathrm{P}>0.01)$ on the growth power of indigofera zollingeriana. Sprouts. Based on the Duncan test results showed that there was an interaction between the two factors causing an increase in the growth power of indigofera zollingeriana sprouts, we can see in table 4 that the best K2L2 treatment showed the highest percentage of indigofera zollingeriana. \%.

From the analysis results, it is assumed that the administration of KNO3 affects the amount of growth of indigofera zollingeriana, this is suspected because KNO3 has a very important element for the growth rate of indigofera zollingeriana. This is in accordance with the statement of Salisbury and Ross, 1985 [2] that potassium nitrate contains two important nutrients needed by plants, namely $44 \%$ potassium and $12 \%$ nitrogen. Nitrogen and potassium are the two macro elements needed by plants.

Similarly, from the time of immersion, it can be assumed that immersion time has a positive impact on indigofera zollingeriana seeds because immersion can soften the outer skin. This is in accordance with the statement of Dolouche in Silombah, 2006 [5] that immersion treatment in water serves to wash substances that inhibit germination and can soften seed skin. Soaking can increase absorption faster.

\section{Conclusion}

The use of KNO with levels of 4 grams and 8 grams had a positive impact on the percentage of germination and height of Indigofera zollingeriana and the duration of soaking 12 hours in the seeds of indigofera zollingeriana also gave a positive effect on the percentage of sprouts and sprouts, and at the best growth use of 8 grams of $\mathrm{KNO}_{3}$ with 8 hours of immersion time.

\section{References:}

[1] Rismunandar. 1999. Hormon Tanaman dan Ternak. PT. Penebar Swadaya. Jakarta.

[2] Salisbury dan C. Ross. 1985. Fisiologi Tumbuhan, Institut Pertanian Bogor, Bandung.

[3] Sihotang, A. R. 1995. Pengaruh Lama Perendaman dan Konsentrasi Kalium Nitrat (KNO3) terhadap Perkecambahan Benih Kemiri. Skripsi Fakultas Pertanian USU. Medan.

[4] Santosa, E., N. Sugiyama., M. Nakata, and O. N. Lee. 2006. Growth and corm production of Amorphophallus at different shading level in Indonesia. Jpn. J. Trop. Agr. 50 (2): 8791. 
[5] Silomba, S.D.A. 2006. Pengaruh Lama Perendaman dan Pemanasan Terhadap Viabilitas Benih Kelapa Sawit (Elaeis guineensis Jaqc.). Institut Pertanian Bogor. Bogor. 7 hlm [1] Rismunandar. 1999. Hormon Tanaman dan Ternak. PT. Penebar Swadaya. Jakarta. 